\title{
Further Delineation of Speckled Lentiginous Nevus Syndrome
}

\author{
Essam I. Al Ageeli, MD \\ Department of Biochemistry, College of Medicine, Jazan University, Saudi Arabia \\ Department of Medical Genetics, Robert Debre Hospital (RDB), Paris, France
}

\author{
Correspondence \\ Dr. Essam I. Al Ageeli \\ P.O Box 114, Jazan, Saudi Arabia \\ e.M: dr.ageeli@gmail.com \\ Submission: 10 May 2016 \\ Accepted: $\quad 15$ Jun. 2016
}

\section{Citation}

Al Ageeli El. Further delineation of speckled lentiginous nevus syndrome. JKAU Med Sci 2016; 23 (3): 57-61. DOI: 10.4197/Med. 23.3.7

\begin{abstract}
Speckled lentiginous nevus syndrome is a recently described condition, characterized by unilateral neurocutaneous manifestations consisting of: speckled lentiginous nevus, hyperhidrosis, muscular weakness and dysesthesia. Skeletal anomalies such as scoliosis, limb asymmetry, and psychiatric manifestations have been also reported. Herein, we report a case of speckled lentiginous nevus syndrome with skeletal anomalies and a pseudo-marfanoid phenotype.
\end{abstract}

\section{Keywords}

Speckled lentiginous nevus; Dysesthesia; Muscular atrophy; Scoliosis; Marfanoid features

\section{Introduction}

$S$ peckled lentiginous nevus (SLN) or nevus spilus is a variable multicolor skin lesion, consisting of a large light-brown patch present at birth or during early infancy superimposed by dark-brown tiny nevi that darken progressively and increase in number and size over time ${ }^{[1]}$. Nevus spilus usually is oval, but can be linear and follow the lines of Blaschko. There are two types of nevi in SLN that are different in their character and histopathology: nevus spilus maculosus is in phacomatosis spilorosea and nevus spilus papulosus in phacomatosis pigmentokeratotica ${ }^{[2,3]}$. Speckled lentiginous nevus is a benign condition but transformation in a malignant melanoma has been reported ${ }^{[3]}$. This dermatologic lesion is described in different disorders: phacomatosis pigmentokeratotica, Schimmelpenning syndrome, segmental neurofibromatosis, LEOPARD syndrome, Carney complex and FACES syndrome.

Speckled lentiginous nevus syndrome (SLNS) was described by Happle as a neurocutaneous manifestation consisting of unilateral speckled lentiginous nevus, hyperhidrosis, muscular weakness and dysesthesia ${ }^{[4]}$, associated with median nerve paresis ${ }^{[5]}$ and skeletal anomalies such as scoliosis, limb asymmetry and psychiatric manifestations ${ }^{[6-9]}$. Speckled lentiginous nevus syndrome was reported in 10 patients ${ }^{[4-14]}$.

We report here a patient with SLNS, skeletal anomalies and a marfanoid phenotype.

\section{Clinical Report}

This Caucasian male was the first child of healthy unrelated parents with unremarkable family history. He was born at term of an uncomplicated pregnancy. At birth; weight was 3800 gram (g), length 56 centimeter $(\mathrm{cm})$ and Occipitofrontal Circumference (OFC) $36 \mathrm{~cm}$. A large hyperpigmented macula was present over left flank area. Cutaneous eruption of unknown origin led to hospitalization for 15 days in early neonatal period. Developmental milestones were normal: he walked at 12 months and began to speak before 18 months of age. Right dorsal scoliosis was observed at the age of 18 months. Café au lait spots on left buttock and thigh appeared in infancy. Cerebral Computerized Tomography (CT) scan, Magnetic Resonance Imaging (MRI) and Electromyography (EMG), prompted by abnormal gait, at 2-year-old were normal. Hyperpigmented spots on the wide 
pigmented macula, and over thumb, $2^{\text {nd }}$ and $4^{\text {th }}$ left fingers were noted between 3 and 6 years. On a biopsy of a pigmented spot, junctional nevus was diagnosed. Histological aspect of dorsal macula was compatible with café au lait spot. At age of 10 years, clinical evaluation noted scoliosis, hemiatrophy of the left side with discrete motor deficit and dysesthesia/hyperalgia on a territory that covered the distribution of nevi. He had no intellectual deficit and followed normal school. At age of 15 years, his height was $154 \mathrm{~cm}$ (- 2 Standard Deviation (SD), and his head circumference was $53 \mathrm{~cm}$ (-2 SD). At last examination, at age of 23 years, he had no obvious facial dysmorphism (long oval face without asymmetry). He had a marfanoid phenotype with arachnodactyly and long, thin toes. Cardiac echography was normal. He had no organomegaly. Genitalia were normal. Neurological examination revealed left sided hyperesthesia and left amyotrophia more prominent in upper limb, hypoplasia of thenars and hypothenars and bilateral hyperreflexia without Babinski sign. He has three large hyperpigmented patches on the left flank, extending to the buttock and anterior aspect of left thigh superimposed by multiple tiny black nevi (Fig. $1 \mathrm{~A}$ and $1 \mathrm{~B})$. Other nevi were present on the ventral and dorsal aspects of left hand fingers (Fig. 1C and 1D). He has no behavioral disturbance. X-ray showed lumbar
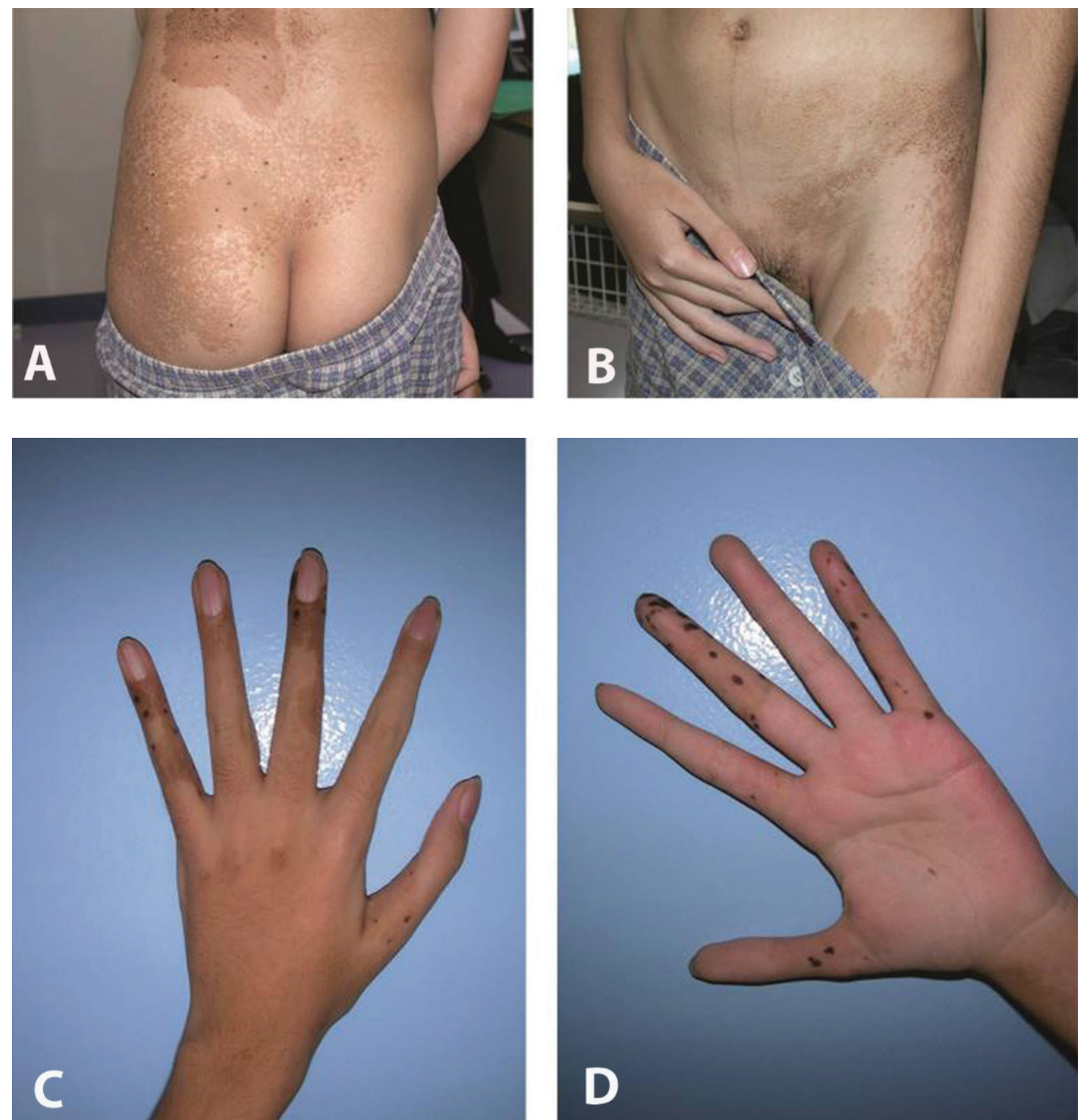

Figure 1. (A) Speckled Lentiginous nevus (SLN) on left flank and buttock, extended to left thigh anteriorly as seen in (B). C) and D) shows arachnodactyly and SLN involved dorsal and ventral aspect left hand fingers. 
scoliosis and vertebral flattening of D12-L1. Cerebral and medullar MRI, ophthalmologic examination, renal and abdominal ultrasound, audiogram, thyroid and growth hormone levels were normal. High resolution single nucleotide polymorphism (SNP) array (ILLUMINA SNP-12 V2. 220000 probes) showed no genomic rearrangement. Screening of neurofibromin 1 (NF1), sprouty related EVH1 domain containing 1 (SPRED1), protein tyrosine phosphatase, non-receptor type 11 (PTPN11), guanine nucleotide-binding protein, alphastimulation activity polypeptide 1 (GNAS1) and protein kinase CAMP-dependent type I regulatory subunit alpha (PRKAR1A) genes were normal.

\section{Discussion}

This patient presents unilateral left side twins spots phenomena with large café au lait patches dotted by black navi, left hemiatrophy, and hemilateral motor deficit with dysesthesia. In addition, he had marfanoid features, with scoliosis and arachnodactyly.

The characteristic skin lesion of this patient is a SLN that typically covers segmental areas, following Blaschko lines, often with a sharp demarcation at the midline, and thus represent a form of skin mosaicism ${ }^{[15]}$. Speckled lentiginous nevus are uncommon. They are usually present at birth or appear in early infancy as common café au lait macules, which later develop background tan-brown hyperpigmentation and small dark pigmented macules. The macular variant of SLN shows dark flat speckles with a relatively even distribution. The papular variant, present in our patient, shows similar light-brown macules superimposed by multiple papular or nodular melanocytic nevi that show a more uneven distribution.

Speckled nevi are observed in several disorders, which were considered in turn in our patient. Segmental neurofibromatosis 1 was found unlikely, as his cutaneous hyperpigmented spots had a clearly different aspect from the homogenous, brown patches of NF1. Noonan- syndrome with multiple lentigines and Legius syndromes, two other RASopathies, were unlikely. In McCune-Albright syndrome, caused by postzygotic mutation in GNAS1, distinctive features include precocious puberty, fibrous dysplasia of bone and endocrine manifestations secondary to endocrine hyperactivity ${ }^{[16]}$. Mutations in the PRKAR1A tumor suppressor gene cause Carney complex, an autosomal dominant disease associated with pigmented lesions reminiscent of Noonan syndrome with multiple lentigines and multiple endocrine manifestations

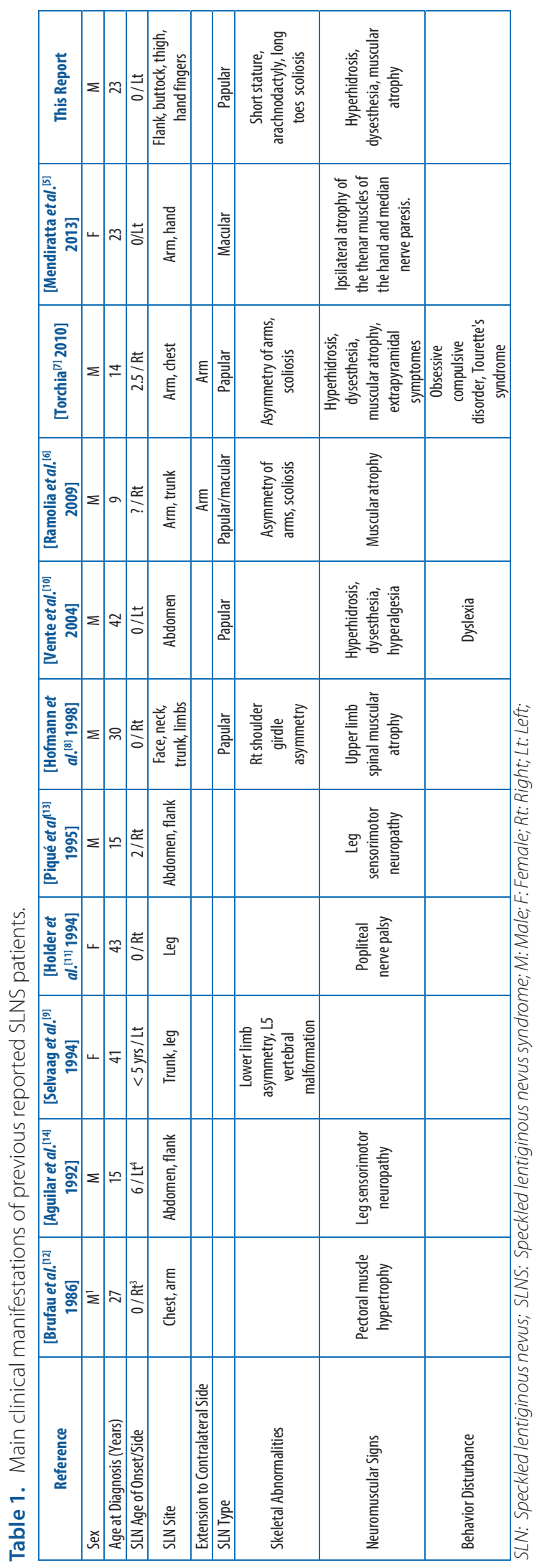


including Cushing's syndrome, myxomas and a predisposition to tumors ${ }^{[17]}$. SLN is also observed with extracutaneous manifestation in phacomatosis pigmentokeratotica and Schimmelpenning syndrome. Organoid sebaceous nevus, mental retardation, seizure, ocular anomalies (ptosis, glaucoma) and facial dysmorphism allow distinction from phacomatosis pigmentokeratotica. coloboma, epibulbar lipodermoid, hemimegalencephaly and anomalies of gyration are distinctive from Schimmelpenning syndrome ${ }^{[18]}$.

Happle ${ }^{[4]}$ suggested in 2002 that unilateral SLN, hyperhidrosis, muscular weakness and dysesthesia represent a distinct neurocutaneous phacomatosis, for which he coined the term "speckled lentiginous nevus syndrome". Seven males and 3 females have been reported with this spectrum (Table 1$)^{[4,6]}$. Speckled lentiginous nevus, papulosus type, is present in a majority of cases. Risk of malignant melanoma transformation exists. Skeletal abnormalities have been reported in several cases ${ }^{[6-9]}$, but our patient appears to be the first to disclose a marfanoid habitus.

\section{Acknowledgments}

The author would like to thank the patient and his family for their cooperation and Professor Alain Verloes for comments and critical review of the manuscript.

\section{Conflict of Interest}

The author has no conflict of interest.

\section{Disclosure}

The author did not receive any type of commercial support either in forms of compensation or financial for this study. The author has no financial interest in any of the products or devices, or drugs mentioned in this article.

\section{Ethical Approval}

Obtained.

\section{References}

[1] Schaffer JV, Orlow SJ, Lazova R, Bolognia JL. Speckled lentiginous nevus: within the spectrum of congenital melanocytic nevi. Arch Dermatol 2001; 137(2): 172-178.

[2] Happle R. Speckled lentiginous naevus: which of the two disorders do you mean? Clin Exp Dermatol 2009; 34(2): 133-135.
[3] Vidaurri-de la Cruz H, Happle R. Two distinct types of speckled lentiginous nevi characterized by macular versus papular speckles. Dermatology 2006; 212(1): 53-58.

[4] Happle R. Speckled lentiginous nevus syndrome: delineation of a new distinct neurocutaneous phenotype. Eur J Dermatol 2002; 12(2): 133-135.

[5] Mendiratta V, Jabeen M, Barara M, Varshney M. Speckled lentiginous nevus syndrome with median nerve paresis: a rare syndrome with a new association. Indian Dermatol Online J 2013; 4(3): 234-235.

[6] Ramolia P, Treadwell P, Haggstrom A. Speckled lentiginous nevus syndrome associated with musculoskeletal abnormalities. Pediatr Dermatol 2009; 26(3): 298-301.

[7] Torchia D. More on speckled lentiginous nevus syndrome. Dermatology 2010; 221(4): 324-325

[8] Hofmann UB, Ogilvie P, Müllges W, Bröcker EB, Hamm H. Congenital unilateral speckled lentiginous blue nevi with asymmetric spinal muscular atrophy. J Am Acad Dermatol 1998; 39(2 Pt 2): 326-329.

[9] Selvaag E, Thune P, Larsen TE. Segmental neurofibromatosis presenting as a giant naevus spilus. Acta Derm Venereol 1994; 74(4): 327.

[10] Vente C, Neumann C, Bertsch H, Rupprecht R, Happle R. Speckled lentiginous nevus syndrome: report of a further case. Dermatology 2004; 209(3): 228-229.

[11] Holder JE, Graham-Brown RA, Camp RD. Partial unilateral lentiginosis associated with blue naevi. Br J Dermatol 1994; 130(3): 390-393.

[12] Brufau C, Moran M, Armijo M. [Nevus on nevus. Apropos of 7 case reports, 3 of them associated with other dysplasias, and 1 with an invasive malignant melanoma]. Ann Dermatol Venereol 1986; 113 (5): 409-418.

[13] Piqué E, Aguilar A, Fariña MC, Gallego MA, Escalonilla P, Requena L. Partial unilateral lentiginosis: report of seven cases and review of the literature. Clin Exp Dermatol 1995; 20 (4): 319-322.

[14] Aguilar A, Gallego M, del-Río E, Martínez E. [Lentiginosis parcial unilateral]. Actas Dermosifiliogr 1992; 83: 646-648.

[15] Altman DA, Banse L. Zosteriform speckled lentiginous nevus. J Am Acad Dermatol 1992; 27(1): 106-108.

[16] Dumitrescu CE, Collins MT. McCune-Albright syndrome. Orphanet J Rare Dis 2008; 3: 12.

[17] Courcoutsakis NA, Tatsi C, Patronas NJ, Lee CC, Prassopoulos PK, Stratakis CA. The complex of myxomas, spotty skin pigmentation and endocrine overactivity (Carney complex): imaging findings with clinical and pathological correlation. Insights Imaging 2013; 4(1): 119-133.

[18] Chantorn R, ShwayderT. Phacomatosis pigmentokeratotica: a further case without extracutaneous anomalies and review of the condition. Pediatr Dermatol 2011; 28(6): 715-719. 


\section{المزيد من العلامات الوصفية لمتلازمة الوحمة المرقطة}

$$
\begin{aligned}
& \text { عصام بن إبراهيم العقيلي }
\end{aligned}
$$

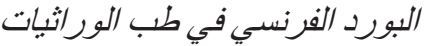

$$
\begin{aligned}
& \text { زمالة الوراثة السريرية - مستشفى روبرتيرت دوبريه ـ باريس }
\end{aligned}
$$

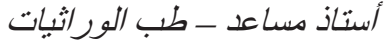

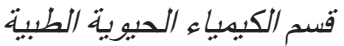

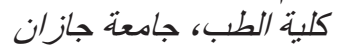

$$
\begin{aligned}
& \text { جازان - المدلكة العربية السعودية }
\end{aligned}
$$

المستخثص. متلازمة الوحمة المرقطة Speckled lentiginous nevus syndrome)، هي حالة وصفت حديثأ، وتثميز بأعر اض عصبية جلدية أحادية الجانب تتكون من: وحمة مرقطة، فرط التعرق، ضعف العضلفة العضلات وضعف الإحساس. أيضا

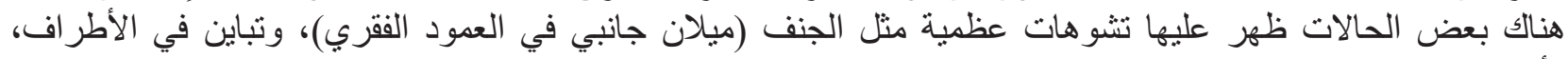

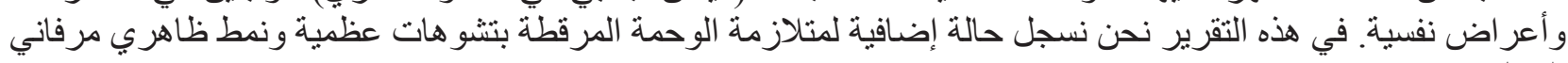

